\title{
PRELIMINARY DIAGNOSES OF NEW SPECIES OF CHAETOMIUM.
}

\author{
By A. H. Chivers.
}

Presented by R. Thaxter. Received, June 16, 1912.

For a considerable time the writer has been engaged in the preparation of an illustrated monograph of the genus Chaetomium but owing to unavoidable interruptions, and delay caused by the preparation of plates, he has thus far been obliged to defer a final publication.

At the time when this work was begun, the only comprehensive paper on the subject was the well known monograph of Zopf (Nova Acta Acad. Leop.-Carol. 42. 1881), but after it was well under way a paper by Bainier appeared in the Bull. de la Soc. Myc. de France (Vol. XXV. Fasc. 4. p. 191. 1910) in which a considerable number of new forms were described and illustrated, some of which prove to be American. Up to the present time, however, there has been no further attempt to make a comprehensive review of the genus or to collate the American forms with the exception of the revision of the Chaetomiaceae in volume III of the "Flora of North America" by H. L. Palliser, who enumerates seventeen species including three unpublished names.

In the course of his work upon these widely distributed fungi the writer has been able to examine a very large series of specimens from various herbaria and exsiccati, and to cultivate many species from diverse sources on various media and through many successive generations. As a result of this examination numerous forms have been added to those previously recorded from America, and a number of new species have been recognized of which it seems desirable to publish the following preliminary diagnoses. In this connection it may be mentioned that all of these forms with two exceptions have been extensively cultivated in a pure condition and that it has been possible to determine with accuracy their range of variation as well as their salient, specific characteristics. 


\section{Chaetomium subspirale, sp. nov.}

Griseum vel roseo-griseum. Peritheciis majoribus, longioribus, $314 \times 213 \mu(300-337 \times 206-224)$, sporidiis irregulariter conglobatis gerentibus; pilis lateralibus numerosis, tenuibus, regulariter et distincte septatis, levibus, basi rectis, apice arcte spiraliter convolutis; pilis terminalibus tenuibus, obscure septatis, pallide-olivaceis, levibus, primum arcte dein laxe spiraliter convolutis; ascis clavatis, octosporis, $45 \times 9.7 \mu$, p. sporif. $24 \mu$; sporidiis subdistichis, pallide olivaceis, limoniiformibus, utrinque apiculatis, $6.4 \times 5.2-5.6 \mu$.

Frequent in cultures of various substrata from New England. Appearing in cultures of dung from Holland and South America.

The species may be distinguished by its characteristic hairs; the lateral ones of which are short, straight, dark below; tightly coiled, hyaline and refractive at the tips; the terminal slender, at first tightly coiled in a delicate spiral, later elongated, twisted rather than coiled and giving the appearance of wooly threads.

\section{Chaetomium sphaerale, sp. nov.}

Griseo-flavis, olivaceo-flavis, aetate aureo-flavis. Peritheciis majoribus, subglobosis, basi rotundatis, apice subconstrictis, $312 \times 276 \mu$ $(300-329 \times 262-300)$, sporidiis regulariter conglobatis gerentibus vel cirrhis instructis; pilis lateralibus numerosis, gracilibus, levibus, regulariter et distincte septatis, successive olivaceis, aureoflavis, pallide flavis, hyalinis, apice collabentibus; aliis subrectis, longioribus, 1-2-ramosis, basi $3.7 \mu$ diam., aliis flexuosis, brevioribus, non ramosis, basi $2.8 \mu$ diam.; pilis terminalibus longis, gracilibus, pilis lateralibus concoloribus, levibus, irregulariter flexuosis vel subspiraliter convolutis, 1-5-ramosis, basi distincte septatis, apice obscure septatis vel subcontinuis; ascis clavatis, octosporis, $48 \times 13 \mu$, p. sporif. $26 \mu$; sporidiis subdistichis, dense olivaceo-brunneis, utrinque umbonatis, limoniiformibus, $7.3-8.1 \times 6.4 \mu$.

In a culture of caterpillars from Reading, Mass.

The perithecium, globose below, with a tendency to narrow above into a neck, distinguishes this species from all others which the writer has studied. The slender delicate hairs and the entire absence of differentiated rhizoids are also significant characteristics. 


\section{Chaetomium quadrangulatum, sp. nov.}

Griseum. Peritheciis majoribus, longioribus, $403 \times 294 \mu$ (333$456 \times 243-350)$, cirrhis longissimis instructis; pilis lateralibus numerosis, tenuibus, rectis, regulariter et distincte septatis, basi olivaceo-fuscis, asperulis vestitis, apice hyalinis, levibus; pilis terminalibus biformibus, aliis spiraliter convolutis, irregulariter pauciseptatis, asperulis vestitis, basi olivaceo-brunneis vel atris, apice dilute coloratis, aliis subrectis, undulatis vel convolutis, irregulariter pauciseptatis, asperulis vestitis, ramosis, basi olivaceo-brunneis vel atris, apice dilute coloratis; ascis clavatis, octosporis, $39 \times 9.7$ p. sporif. $21 \mu$; sporidiis pallide olivaceis, a fronte visis subquadrangulatis, a latere ovatis, $7.3 \times 6.3 \mu(6.4-8 \times 5.6-6.4)$.

Cultivated on dung from Cambridge, Mass. Appearing also on dung from Chile and from Little Swan Island, Gulf of Mexico (R. Thaxter).

The species may be easily identified by the spores which, when seen in face view, are four sided and four angled but, when seen in profile, are oval. Chaetomium quadrangulatum and Chaetomium trigonosporum are the only species known to the writer which possess spores with angles, the former having spores clearly quadrangular, the latter clearly triangular.

\section{Chaetomium convolutum, sp. nov.}

Cyano-griseum. Peritheciis magnitudine mediis, globosis, $244 \times$ $232 \mu(236-254 \times 224-240)$, cirrhis instructis; pilis lateralibus paucis, gracilibus, rectis, regulariter et distincte septatis, basi olivaceo-flavis, asperulis vestitis, apice hyalinis, sparse asperulis vestitis; pilis terminalibus undique asperulis vestitis, olivaceo-atris, subcontinuis vel irregulariter pauciseptatis, 8-10 spiraliter convolutis, ad ipsam apicem convolutionibus terminalibus regulariter successive minoribus; ascis clavatis, octosporis, $56.4 \times 10 \mu$, p. sporif. $27.4 \mu$; sporidiis pallide olivaceis, ovatis vel limoniiformibus, utrinque obtusis, subapiculatis, $8-8.4 \times 6.4 \mu$.

Cultivated on mouse dung from Germany.

Apparently a rare species having appeared but once. The species may be identified by the distinct blue color of the plant when seen with the naked eye or a hand lens, and by the long spreading terminal hairs whose long series of coils taper abruptly to a blunt point. 


\section{Chaetomium spinosum, sp. nov.}

Aureo-flavum. Peritheciis magnitudine mediis, subglobosis, 290$224 \mu \quad(273-318 \times 206-262)$, cirrhis instructis; pilis lateralibus numerosis rectis, rigidis, acutis, irregulariter et parum distincte septatis, basi atrobadiis, asperulis vestitis, apice hyalinis, levibus; pilis terminalibus rectis, rigidis, acutis, asperis vestitis, ramosis, ramis ramulisque dilute olivaceis; ascis clavatis, octosporis, $41 \times 7.5 \mu$, p. sporif. $22 \mu$; sporidiis subdistichis, pallide olivaceis, oviformibus, $5.9 \times 3.9 \mu(5.6-6.4 \times 3.2-4)$.

Growing in cultures of dung from Buenos Ayres (R. Thaxter).

This is, apparently, a rare species having appeared but once. The egg-shaped spores and the branched terminal hairs are peculiar to the species. From the dark, stiff, spine-like shafts or the terminal hairs arise slenter, delicate, irregularly swollen and constricted branches, from which secondary branches arise. As the cirrhus of spores forms the branches rise in the form of a column and in this way a support is formed for the spore mass.

\section{Chaetomium ampullare, sp. nov.}

Ochraceum. Peritheciis majoribus, longissimis, $489 \times 147 \mu$ (456$532 \times 137-167)$, sporidiis irregulariter conglobatis gerentibus; pilis lateralibus paucis, gracilibus, regulariter et distincte septatis, basi rectis, olivaceo-fuscis, asperulis vestitis, apice collabentibus, levibus; pilis terminalibus longis, gracilibus, distincte et regulariter septatis, successive aureo-brunneis, aureo-flavis, hyalinis; levibus, ramosis, in fila hyalina elongatis; ascis clavatis, octosporis, $45 \times 9.7 \mu$, p. sporif. $23 \mu$; sporidiis subdistichis, laete olivaceo-flavis, utrinque umbonatis, limoniiformibus, $8.1-8.9 \times 6.4 \mu$.

On culture of sail cloth from Lowell, Mass. On dung from North Carolina (R. Thaxter).

The species is clearly characterized by the very much elongated bottle-shaped perithecium, and by the terminal hairs which are drawn out into long, hyaline, tangling, easily collapsing threads.

Chaetomium aureum, sp. nov.

Griseum, pallide-olivaceum, lutescens, demum aureo-flavum. Peritheciis minutis, globosis, $127 \times 115 \mu(110-140 \times 105-123)$, cirrhis instructis, pilis lateralibus numerosis, tenuibus, rectis vel flexuosis, 
regulariter et distincte septatis, olivaceo-flavis, asperulis vestitis; pilis terminalibus olivaceo-flavis, regulariter septatis, asperulis vestitis, arcuatis, apice subrectis vel incurvatis; ascis clavatis, octosporis, $42 \times 10 \mu$, p. sporif. $26 \mu$; sporidiis olivaceo-brunneis, irregulariter ovatis, utrinque apiculatis, $9.8 \times 5.4 \mu(9.4-11 \times 4.7-5.6)$.

On paper, dung and other materials of various kinds from New England. In cultures of old paper from Java (R. Thaxter).

The small size and characteristic golden yellow color clearly distinguish this species from all others except Chaetomium trilaterale and Chaetomium fusiforme. From the former of these it differs in that the spores are discharged in long black cirrhi, in the comparative obscurity of the perithecial hairs at maturity, in the incurved tips of the terminal hairs, and in the irregular, oval shape of its spores. From the latter it differs also in producing long black cirrhi, in the incurved extremities of its terminal hairs, and in the size of its spores and their irregular oval shape.

\section{Chaetomium fusiforme, sp. nov.}

Griseum vel pallide olivaceum. Peritheciis minutis, subglobosis, $120 \times 102 \mu(116-123 \times 101-125)$, cirrhis carentibus; pilis lateralibus numerosis, tenuibus, flexuosis, regulariter et distincte septatis, olivaceo-flavis, asperulis vestitus; pilis terminalibus crassioribus, asperulis vestitis, olivaceo-brunneis, regulariter et distincte septatis, arcuatis, apice circinantibus vel subconvolutis; ascis clavatis, octosporis, $48 \times 11 \mu$, p. sporif. $32 \mu$; sporidiis laete olivaceo-flavis, vel olivaceo-brunneis, longis, angustis, subfusiformibus, apice rotundatis vel apiculatis, $15.8 \times 5.4 \mu(15-16 \times 4.8-5)$.

On paper from Alabama (Herb. R. Thaxter).

The long narrow spores distinguish this form from all other species of Chaetomium. In general characteristics it most nearly resembles Chaetomium aureum and Chaetomium trilaterale, but differs from both in the long, slender, fusiform spores.

\section{Chaetomium trilaterale, sp. nov.}

Olivaceo-flavum. Peritheciis minutis, subglobosis, $106 \times 94 \mu$ (100-110 × 90-97), cirrhis carentibus; pilis lateralibus numerosis, gracilibus, longioribus, regulariter et distincte septatis, aureo-flavis, basi rectis, asperulis vestitis, apice 1-3 spiraliter convolutis, levibus; pilis terminalibus irregulariter septatis, olivaceo-brunneis, asperulis 


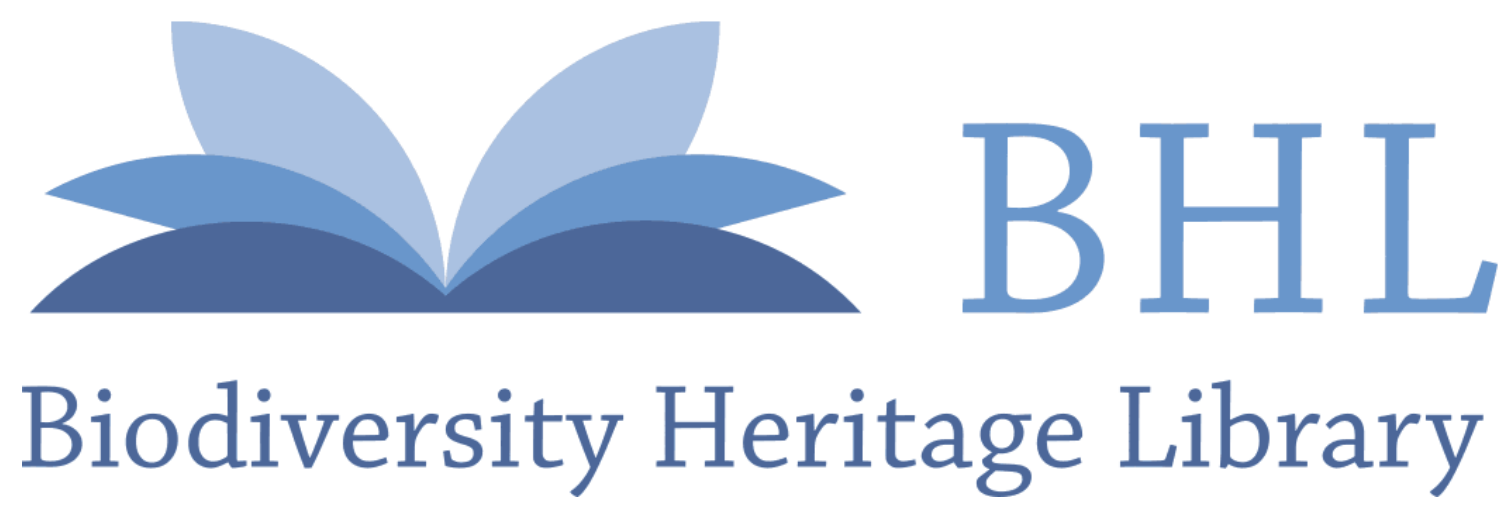

Chivers, Arthur Houston. 1912. "Preliminary diagnoses of new species of Chaetomium." Proceedings of the American Academy of Arts and Sciences 48(4), 83-88.

View This Item Online: https://www.biodiversitylibrary.org/item/28022

Permalink: https://www.biodiversitylibrary.org/partpdf/246325

\section{Holding Institution}

MBLWHOI Library

\section{Sponsored by}

MBLWHOI Library

\section{Copyright \& Reuse}

Copyright Status: NOT_IN_COPYRIGHT

This document was created from content at the Biodiversity Heritage Library, the world's largest open access digital library for biodiversity literature and archives. Visit BHL at https://www.biodiversitylibrary.org. 